Jurnal ASPIKOM, Vol. 6, No. 2, July 2021, pp. 413-428

P-ISSN: 2087-0442, E-ISSN: 2548-8309

DOI: http://dx.doi.org/10.24329/aspikom.v6i2.908

\title{
Cross-Cultural Adaptation Process of Japanese Expatriates in Indonesia
}

\section{Proses Adaptasi Antarbudaya Pada Ekspatriat Jepang di Indonesia}

\author{
Windy Melliani Mandari, Rino Febrianno Boer* \\ Institut Komunikasi dan Bisnis LSPR, Jalan KH Mas Mansyur Kav.35, Jakarta Pusat, \\ Indonesia \\ *Corresponding author, e-mail: rino.fb@lspr.edu
}

\begin{abstract}
Cross-cultural adaptation process is an ongoing issue for expatriates while working abroad, including Japanese expatriates working in Indonesian companies. This research aims to know the critical point and adaptation process of Japanese expatriates. The research method used was ethnography. Primary data collection techniques were in-depth interviews and observations. This research also included secondary data. Findings revealed that the adaptation process had an important role as it could lead to a comfortable interaction and reduce miscommunication at work. Important factors in the adaptation process were language fluency, work culture adjustment, media uses, daily interaction with Indonesians, interaction among Japanese in Indonesia, and real assistance for expatriates. There were three stages that expatriates had to go through, i.e., preparation, active, and final stage. The critical points in the adaptation process were language skills and willingness to accept changes.
\end{abstract}

Keywords: Communication; Cross-cultural adaptation; Japanese expatriates

\begin{abstract}
Abstrak
Proses adaptasi budaya masih menjadi isu bagi ekspatriat yang bekerja di luar negara asal termasuk ekspatriat Jepang yang bekerja di perusahaan Indonesia. Penelitian bertujuan mengetahui titik kritis dalam proses adaptasi ekspatriat Jepang. Metode penelitian menggunakan etnografi. Teknik pengumpulan data primer berupa wawancara mendalam, observasi, dan data sekunder. Hasil penelitian ini menemukan bahwa proses adaptasi memiliki peran penting karena dapat menimbulkan kenyamanan berinteraksi dengan sesama pegawai serta mengurangi miskomunikasi dalam bekerja. Faktor penting dalam proses adaptasi yaitu kompetensi bahasa Indonesia, penyesuaian budaya kerja, penggunaan media, interaksi secara langsung dengan orang Indonesia, interaksi dengan orang Jepang di Indonesia, dan bantuan nyata untuk ekspatriat. Terdapat tiga tahapan yang dijalani oleh orang yang tinggal dan bekerja di luar negara asal yaitu tahapan preparation, active, dan final. Titik kritis dalam proses adaptasi yaitu keterampilan dalam mengunakan bahasa lokal baik secara lisan maupun tertulis, dan sikap mental untuk bersedia menerima perubahan.
\end{abstract}

Kata Kunci: Adaptasi antarbudaya; Ekspatriat Jepang; Komunikasi 


\section{Introduction}

The presence of expatriates in Indonesia is naturally easy to find. Employees whom the company asks to work abroad have an important role in international business. Three among those reasons for sending expatriates are to start company operations, develop company business operations and perform other tasks related to company interests in the respective country (Yusof, 2000). Japanese expatriate is one of many foreigners who are working in Indonesia. Japanese expatriates occupy the secondhighest position after those from China with total number of 13,897 workers (Nathaniel, 2019). Japan, as a country with the largest economy in the world after United States of America and China, is a country in Asia that its development is comparable to Western countries. To develop their business, many Japanese companies have invested or established manufacturing companies abroad one of which is in Indonesia. The establishment of Japanese companies in Indonesia closely relates to the foreign workers from Japan sent to Indonesia to manage the business. These Japanese expatriates must make adaptation to local culture. Individuals need to adapt and respect the customs and habits of local communities if they are to succeed in a new environment (Aminullah, Lestari, \& Tripambudi, 2015).

Cultural differences between Japanese expatriates and local Indonesian residents can be a source of problems if these are not handled properly. Therefore, tre is an urgency to understand and appreciate people who are different from ourselves (Lustig \& Koester, 2010). Japanese expatriates are spread in various regions in Indonesia such as in Central Java. Based on Central Java Province Manpower and Transmigration Office data there are 1,627 Japanese expatriates in the province (Central Java Provincial Government, 2020). It is the third-largest number of expatriates after China and Korea. Some of these expatriates are listed as working for foreign investment companies like PT Semeru Karya Buana (SKB) in Semarang. SKB's core business is furniture production. There are 190 Indonesian employees and four (4) Japanese expatriates in the company. The company has its headquarters in Tokyo, Japan, i.e., Sakura Furnishing Corporation (SFC).

Expatriates often experience confusion in adapting due to personal and cultural changes between their place of origin and the country where they work (Rahardjo, Dwiningtyas, \& Pradekso, 2018). The failure of the expatriates to adapt and carry out their duties will affect not only themselves but also the high cost their companies must incur. The direct cost of a failed assignment can range from $\$ 250,000$ to $\$ 1$ million, and the annual cost of failures to all US companies is estimated at $\$ 2$ billion (Burgess, 2016). Therefore, expatriates must be able to face the challenges of adapting to anyone, anytime, and anywhere. The experience of expatriates working outside the home country frequently links to cross-cultural adaptation. Kim (2017) mentions that a tool for adaptation is communication. In companies, communication among employees is important in supporting the companies' success. Particularly with expatriates, companies must ensure that communication between employees and cultures can run well. Many problems in companies arise due to communication or miscommunication. However, it can actually be resolved in a simple way, i.e., through clear communication channels (Ganapathi \& Panchanatham, 2014).

Most adaptation studies show a phenomenon from a culture shock perspective such as in those studies by Kaye and Taylor (1997), Rajasekar and Renand (2013), Shi and Wang (2013), also Anjalin, Mazumdar, and Whiteside (2017). Likewise, in Indonesia, many researchers have investigated this topic of culture shock perspective, 
e.g., Arfiani and Febri (2013), Turistiati (2016), Perdhana, Sawitri, and Siregar (2019), also Mihayo (2019). Studies on expatriates in Indonesia generally use subjects from Malaysia and India (Imelda \& Elsera, 2018), Australia, China, India, Singapore, America, and the Philippines (Santoso, Elyadi, \& Satriany, 2018), Thailand (Rodsai, Stoffers, \& Talim, 2017), and Hispanic-American (Cordovez, 2018). However, studies on Japanese expatriates have not widely conducted in Indonesia. Only a few researchers are investigating the adaptation process of Japanese expatriates, such as the adaptation of Japanese expatriates to culture shock in Surabaya (Kirana, 2012) and adaptation of Japanese expatriates at PT Tokyu Land Indonesia which analyzes intercultural communication between Japanese and local staff through the intercultural communication model from Gudykunst and Kim. The research examines barriers that occur in intercultural communication between them and figures out the methods to overcome these barriers (Febiyana \& Turistiati, 2019). This fact becomes interesting in the realm of research on Japanese expatriates in Indonesia from a different theoretical perspective. Aside from that, most of the research on culture shock used U-Curve models then developed into $\mathrm{W}$-curve models. Unfortunately, these models have led some to conclude that the adaptation process can be generalized, and empirical evidence to support the models is insufficient (Samovar, Porter, McDaniel, \& Roy, 2017). It leads to a new development of adaptation process following the formula like "stressadaptation-growth" proposed by Young Yun Kim.

Some studies employing the intercultural adaptation theory by Young Yun Kim have been conducted. Among them is adaptation research of American expatriates in South Korea by Kim (2008), immigrants in Finland (Sommier, 2012), Hispanic youth in relation to the dominant cultural values and practices embodied in American public school (Semmler \& Kim, 2014), North Korean defectors in Los Angeles (Ahn \& Kim, 2015), and Chinese students in the Upper Northern Thai Universities (Kang, Yossuck, Panyadee, \& Ek-lem, 2019). In Indonesia, this theory is often used to study the adaptation of students, such as adaptation of international students at Muhammadiyah University of Surakarta (Widiyaningrum, 2017), Indonesian students in Australia (Soemantri, 2019), Papuan students in Surabaya (Hapsari, 2019), international students of Sebelas Maret University in Solo (Yurianti, Pranawa, \& Yuhastina, 2020). In addition, there is also adaptation process of marital partners between Bugis and Banyuasin ethnicities in Sungsang Village, Banyuasin District (Somad, 2020), the process of creating harmony (ethical dialogue) between Hindus and Muslims through local wisdom (Saihu, 2019), and the influence of ICT and pop culture on behavior shift of students year 2016 at UNIKOM English literature study program (Dewi \& Susilawati, 2018).

Therefore, it can be said that the novelty of this study compared to previous studies is the employment of Japanese expatriate informants who are still very rarely recruited as participants in other similar studies. Furthermore, the use of integrative cross-cultural adaptation theory within the context of this research topic is not widely used. This research focuses on the experience of culture shock, the stages of culture shock, and ways to overcome culture shock. This research strives to analyze five factors that can facilitate or hinder the adaptation process described by Kim (2017). From the theory development perspective, this research has incorporated factors related to the work environment in detail and follows the 'stress-adaptation-growth' approach. Research conducted by Hapsari (2019) is closely similar to this research. However, the informants participated in the research were students. This study found out that there 
were three stages followed by people who lived and worked outside their home countries.

Integrative cross-cultural adaptation theory conceptualizes adaptation as a dynamic interaction between people and their environment. Kim (2001) defines adaptation as "the dynamic process by which individuals, upon relocating to new, unfamiliar, or changed cultural environments, establish (or reestablish) and maintain a relatively stable, reciprocal, and functional relationship with those environments". Kim (2017) identifies five factors that can facilitate or hinder the process of intercultural adaptation. The first factor is personal communication, defined as cognitive, affective, and operational capacity to communicate in the host environment. The second one is social communication which is defined as participation of newcomers in interpersonal dan mass communication activities in the host environment. The environment is the third factor which is defined as a condition for interacting within personal and social (host, ethnic) communication activities. The fourth factor is predisposition which consists of preparedness for change, ethnic proximity, dan adaptive personality. Lastly, the aforementioned factors directly or indirectly explain and predict the difference in rates and levels of intercultural transformation.

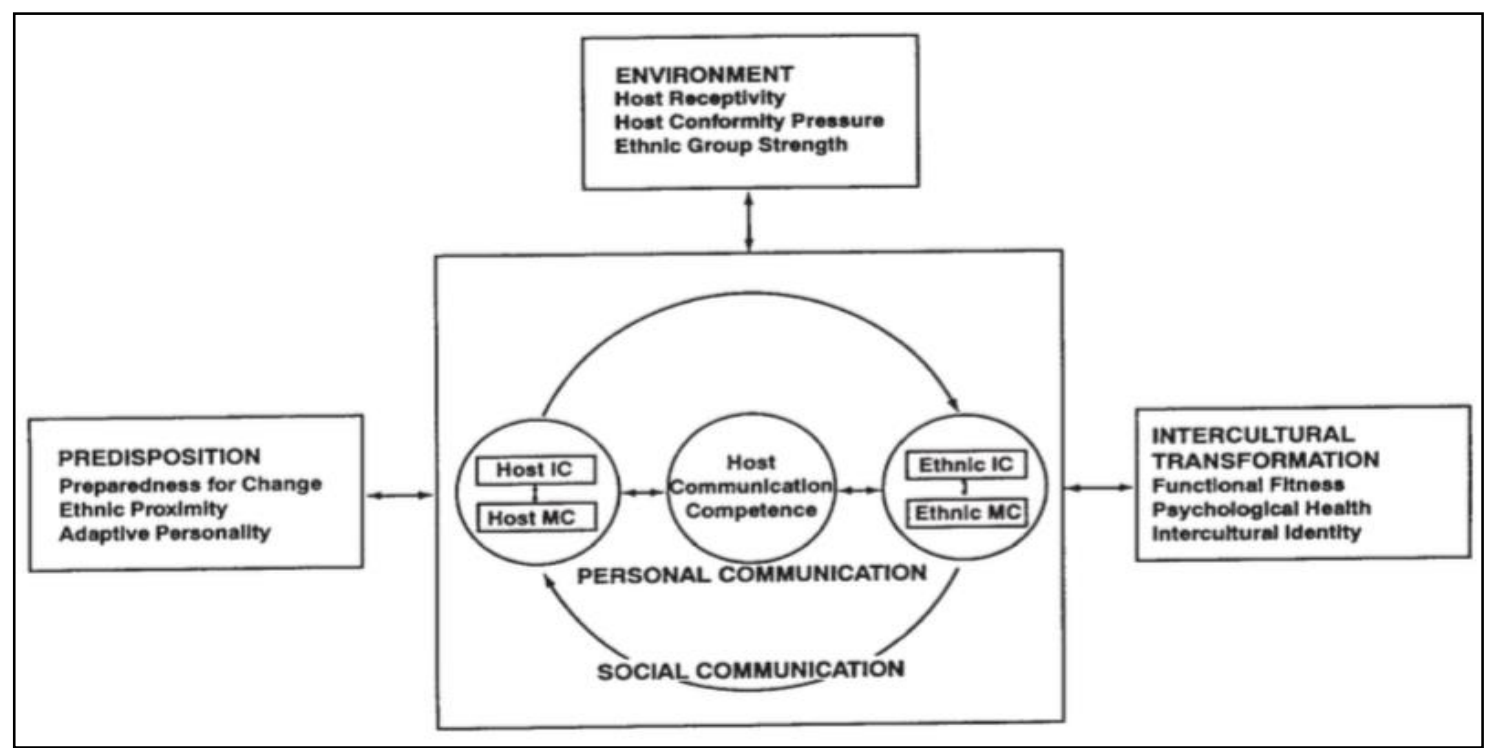

Figure 1. Factors Influencing Cross-Cultural Adaptation: A Structural Model (source: Kim, 2001)

Based on the explanation above, the objective of this present study is to explore the communication and adjustment experiences of Japanese expatriates at SKB from the perspective of integrative communication theory of cross-cultural adaptation by Kim (2017). This research aims to find out why the adaptation process is important for expatriates who work outside their home country, how Japanese expatriates carry out the adaptation process, and what critical points present in the adaptation process of Japanese expatriates when they are working in Indonesia.

\section{Method}

This study uses an ethnographic research method. According to Cresswell and Poth (2018), ethnography is a process and result of a group's research. Ethnography depicts a picture of individuals, groups or/and culture so that it can provide conclusions whether they are directly expressed or implied (Neuman, 2014). Various sources and 
views will be used to see and to understand an event or problem that occurs. Ethnographers must follow, observe, interview, and participate in the routines of the people they study. This allows them to capture meanings, behaviors, intentions, and interactions that are often glossed by methods that are more distant or contrived (Jerolmack \& Khan, 2018). Using the ethnography method, the researchers seek to observe the informants as Japanese people. Even though the adaptation process is done individually, but this research perceives the informants as Japanese in general.

This part presents results/findings and analysis of the findings. Figures or graphs can also be presented here to support your findings. We suggest that you mention supporting instrument(s), in forms of illustration, figure, photograph, table, and graph. Each instrument must be orderly numbered and given a title, followed by source from which you make the citation. Should the instrument is the result from the author's analysis, please write: 'source: author's analysis.'

In addition, this part also contains reflection/discussion according to the research findings. In presenting the discussion, use a comprehensive explanation in order to elaborate the whole data found during the research. By doing so, you can fill gap of knowledge. Findings that rely on meaning construct tends to present a theoretical framework, so there will be an unnecessary repetition as it has been presented in the research methodology.

Four Japanese expatriates with the following backgrounds working at SKB became informants for this study. Researchers also interviewed four local staff who worked at SKB to confirm and to gather a more profound understanding. The four local staff were directly under the position of the Japanese expatriates.

Table 1. Japanese Expatriates’ Demographic Data

\begin{tabular}{|c|c|c|c|c|c|c|c|}
\hline No & Name & Age & $\begin{array}{c}\text { Last } \\
\text { Education }\end{array}$ & $\begin{array}{c}\text { Position at } \\
\text { SKB }\end{array}$ & Gender & $\begin{array}{l}\text { Work } \\
\text { Period } \\
\text { at SKB }\end{array}$ & $\begin{array}{c}\text { Experience } \\
\text { Work } \\
\text { Abroad }\end{array}$ \\
\hline 1. & $\begin{array}{l}\text { Tomotaka } \\
\text { Mizuguchi } \\
\text { (TM) }\end{array}$ & 45 & $\begin{array}{l}\text { Bachelor } \\
\text { Degree }\end{array}$ & $\begin{array}{l}\text { President } \\
\text { Director }\end{array}$ & M & 22 years & No \\
\hline 2. & $\begin{array}{l}\text { Masaya } \\
\text { Tateishi } \\
\text { (MT) }\end{array}$ & 39 & $\begin{array}{l}\text { Bachelor } \\
\text { Degree }\end{array}$ & $\begin{array}{c}\text { Production } \\
\text { Manager }\end{array}$ & M & 7 years & No \\
\hline 3. & $\begin{array}{l}\text { Tanaka Yuji } \\
\text { (TY) }\end{array}$ & 50 & $\begin{array}{c}\text { Vocational } \\
\text { High } \\
\text { School }\end{array}$ & $\begin{array}{l}\text { General } \\
\text { Manager }\end{array}$ & M & $\begin{array}{c}7 \\
\text { months }\end{array}$ & No \\
\hline 4. & $\begin{array}{l}\text { Naoko } \\
\text { Tanaka (NT) }\end{array}$ & 47 & $\begin{array}{l}\text { Bachelor } \\
\text { Degree }\end{array}$ & $\begin{array}{c}\text { PPCI } \\
\text { Manager }\end{array}$ & $\mathrm{F}$ & $\begin{array}{c}7 \\
\text { months }\end{array}$ & No \\
\hline
\end{tabular}

The data collection techniques were carried out using in-depth interview and observation while secondary data were also employed. The researchers observed and recorded events at the research location. The analysis process in this study uses interactive models from Miles, Huberman, and Saldana (2014) and the researchers test the validity of data using triangulation from Denzin and Lincoln (2018).

\section{Results and Discussion}

According to the definition, these four expatriates can be referred to as Expatriate Assignments (EA) because they reside outside their home countries after getting 
assignments from the company that has branches in other countries (Inkson, Pringle, Arthur, \& Barry, 1997)In addition, the four expatriates previously had experience working with other Japanese employees, generally more than 2 years before being assigned to work in Indonesia.

\section{Personal Communication}

Responding to questions about host language competence, Japanese expatriates were lack of Indonesian language competence in daily life but were more skilled in the office. TM claimed to know, understand, write, read, and pronounce words or sentences in the Indonesian language. TM did not find it challenging to speak Indonesian in the office. However, he admitted that he still found it difficult when talking to Indonesians outside the office such as with workers in a shop. This is confirmed by the statement from 2 local staff that said TM's language structure sometimes might be incorrect. However, Indonesian employees understood the Indonesian used by TM because they had worked with him for a long time. When they did not get what TM meant, they asked other Indonesian friends who possibly understood him.

On the other hand, MT admitted that he had not fully mastered the Indonesian language. According to local staff, the Indonesian language ability of MT was quite good despite a lack of understanding of the information provided in the Indonesian language. However, MT found it easier to talk to Indonesians in the office than outside the office because local staff could easily understand MT. This was confirmed by local staff that MT sometimes still had difficulty understanding Indonesian conversations quickly. When interacting with MT in Indonesian, it had to be done slowly. MT was still hesitant to speak in Indonesian in his daily life outside of work, but at work, he was sure that he was well understood by local staff.

Other expatriates, TY and NT, rated their Indonesian language skills to be only $5 \%$ because they still found it difficult to listen to Indonesian language conversations. This made communication in the organization limited, and miscommunication frequently occurred. It took a long time to understand the meaning which TY and NT tried to convey to local staff. TY and NT also stated that the situation frustrated them sometimes. The language barrier can be frustrating and can cause miscommunication. However, it is better if participants are aware of the difficulties so that it will be easier to adapt (Samovar, Porter, McDaniel, \& Roy, 2017). TY and NT said it was easier to use Indonesian in the office because they were more familiar with the expressions used for work such as sentences for asking for help, names of materials for furniture production, names of furniture parts, and other words related to work.

Kim (2017) explains that the affective aspect of host communication competence is a motivation for newcomers. The motivation comes from the affective component involving an individual's emotion in a communication situation (Liu, Volcic, \& Gallois, 2015). Challenges in communicating with Indonesians motivated TM to learn the Indonesian language. TM felt that he had been able to communicate well using the Indonesian language in the $5^{\text {th }}$ month since his arrival. Furthermore, MT began to adapt to the environment in Indonesia after 6 months of arrival by learning Indonesian. According to him, his language skills greatly affected the adaptation process in the office, so learning Indonesian was a must. For TY, his adaptation to the environment in Indonesia, particularly among local staff, required him to have good communication skills in Indonesian language. The awareness of his limitation in Indonesian language made TY highly motivated to learn the language. The level of miscommunication between TY and Indonesian employees reached 50\%, and it was what made it hard for 
him to adapt to employees in Indonesia. On the other hand, NT found difficulties to adapt to employees in Indonesia due to language constraints in which employees used the Indonesian language and Javanese when working. The difficult adaptation due to language constraints made NT decide to study the Indonesian language seriously. NT also stated that her level of miscommunication with local staff remained at 50\%. From the explanation of the affective components above, it was found that the four Japanese expatriates had the motivation to learn the Indonesian language.

The most striking feature of Japanese expatriates' efforts to strengthen and maintain a reciprocal relationship with Indonesian employees and local residents was learning Indonesian. Not only was it beneficial because it facilitated two-way communication smoothly, but it led to a perception that the expatriates were considered as adaptive, flexible, and willing to learn individuals. Local staff who worked with the ex-pats also got positive things from their improving Indonesian language skills, namely understanding and being understood by expatriates when communicating. Furthermore, for companies, smooth communication will create a smooth production process. To efficiently achieve this goal, companies should oblige ex-pats to adapt to the corporate environment quickly. This will make it easier for expatriates to carry out their jobs and improve their performance. Good adaptation done by ex-pats should not negatively impact the company, particularly the adaption accomplished by ex-pats at SKB, in this case, who were at the managerial level whose responsibility was big. The ability to convey messages to subordinates in clear Indonesian would make it easier for all parties to carry out their respective jobs.

From the explanation of operational components, it was found that the four expatriates used the Indonesian language in their interactions with Indonesians, particularly Indonesian employees. However, the frequency of using the Indonesian language of each Japanese expatriate varied from one to another. For example, TM said that he used Indonesian language as his main language and Japanese language as the second. Almost the same with TM, MT admitted that $80 \%$ use of Indonesian language occured because he often held meetings with Indonesian employees. However, outside the office he rarely speaks Indonesian. The other expatriate, TY used Indonesian language for about $50 \%$ and Japanese for 50\%. Due to his limitations in using Indonesian language, TY used a lot of nonverbal communication to minimize miscommunication with the local staff. Moreover, understanding nonverbal cue in communication between people with different geographical background is extremely important to avoid any problems in communication (Mitrovic \& Vujovic, 2017). Meanwhile, NT had the lowest percentage of using Indonesian language at $20 \%$ and still made Japanese as her main language.

\section{Work Culture Differences}

Along with language differences, all ex-pats mentioned a different work culture between Japan and Indonesia that posed a culture shock. TM felt that Indonesian employees lacked a sense of responsibility. For example, an Indonesian employee did not express his opinion because he wanted to avoid the responsibility as a consequence of expressing their opinion. Moreover, because the regional minimum wage in Indonesia always increases every year, TM saw that local staff were seen satisfied and therefore, they worked as little as possible. TM stated that the mindset of Japanese and Indonesian people was different. While Japanese people tended to think of ways to make a job effective, Indonesians did not think the same. TM also explained that local staff often applied for permits or leave. Most of the reasons for permission or leave were 
due to family while in Japan that hardly happened. Japanese employees did not take permission or leave because they did not want to interfere with the company's operation. In addition, MT mentioned that Indonesian employees did not carry out standard operational procedures (SOP) when they did their work. MT also saw that the cultural customs were different from those in Japan, such as in terms of reprimanding matters. For example, he could not remind or scold an Indonesian employee in front of other employees. According to TY, local staff concerned and accomplished only their own work, causing teamwork to be not solid. TY also revealed that using his right hand to point to something was more polite than using the left hand. In Japan, using the right or left hand is the same. The rhythm of work in Indonesia was also perceived to be slower than that in Japan. Another expatriate, NT stated that there was a difference in work culture which existed in Indonesia but did not in Japan, namely the existence of job restrictions in a company. For example, division $\mathrm{X}$ did not help division $\mathrm{Y}$. Meanwhile, in Japan all divisions would mutually help each other.

In connection with the differences in work culture between Japan and Indonesia, all expatriates had found a way to deal with. Firstly, according to TM, it included the implementation of 5S (seiri, seiton, seiso, seiketsu, shitsuke) in the company, implementation of PDCA (planning, do, check, act), tolerance of leave or permits for Indonesian employees, and daily morning meeting at $9 \mathrm{AM}$ to ensure coordination among divisions and minimize miscommunication and errors in the workplace. Secondly, according to MT, the company should provide reports on the work results of Indonesian employees, check work every one hour, and make a job registration used to check the employment of Indonesian employees. If something went wrong, MT called the Indonesian employee and scolded him in an empty room instead of in front of other employees. Thirdly, according to TY, the company was to apply a fast work rhythm to Indonesian employees, to give direct instructions to other divisions if there were divisions that needed assistance, to have a timetable to get work done on time, and to adapt and respect Indonesian culture. At that moment, TY was getting used to pointing or doing something with his right hand. Finally, the way NT built work cohesion was by motivating her subordinates to help each other among divisions.

\section{Interpersonal Communication Contacts and Activities}

Regarding the question about their interpersonal relationship and social activities in Indonesia, the four expatriates said that local staff was neither friends nor best friends but colleagues who had the same goal of advancing the company. However, TM said that he had 30 to 40 Indonesian friends who lived in Semarang, Jakarta and Medan outside the office. Then, MT claimed to have 5 Indonesian friends who lived in Semarang. He said that at least once a month, he communicated and met his Indonesian friend. However, TM and MT said they had gone out with local staff. They admitted to having gone to karaoke, eating together, and breaking the fast together with several local staff. They also attended a wedding held by local staff to congratulate them. From these findings, it can be said that TM and MT could remove work attributes when they were with local staff outside the company. Next, TY and NT said they had neither friends nor best friends in Indonesia. They felt that their life in Indonesia was preoccupied with work so that they had not had the chance to build friendships with Indonesians. Therefore, they had priority first to improve the Indonesian language to communicate at work.

In order to make communication in organizations faster and easier, an organization applies various communication models such as by telephone, face-to-face

Cross-Cultural Adaptation Process of Japanese Expatriates in Indonesia (Windy Melliani Mandari) 
communication, memos, bulletin boards, e-mails, and the uses of other technologies to facilitate communication activities (Santra \& Giri, 2009). From the interview results, the four expatriates utilized any technology to make communication easier. It was revealed that all expatriates used Whatsapp and Line to communicate with local staff. Apart from Whatsapp, they also used e-mail and memos to communicate with Indonesian employees. The use of memos was intended to make Indonesian employees not forget about a given assignment. Memos could be handwritten or sent via WhatsApp.

Related to interpersonal communication with fellow ethnic groups, all expatriates knew that there was a community for Japanese people in Indonesia, particularly in Semarang, i.e., Japan's Club. Each Japanese expatriate had viewpoints regarding their participation in this community. Moreover, each expatriate had motivation or purpose to join it. According to TM, Japan's Club was useful to get a variety of information and could relieve fatigue by playing golf or fishing together. According to MT, Japan's Club was useful as the only place where he could speak Japanese. Seminars held frequently by Japan's Club also made him learn to understand rules applied in Indonesia. According to TY, Japan's Club served as a place to communicate in Japanese and exchange information among members. Meanwhile, NT had a different opinion. She said that Japan's Club activity was mainly playing more golf, which made her uninterested. She preferred to spend time resting at home because she had been working during the week.

\section{Environment}

Kim (2001) states that the acceptance of the host can be seen from the rules of the host that lighten or burden newcomers. From the interview results, all expatriates expressed that there was a regulation from the Indonesian government that was burdensome for them. TM explained that the regulations on termination of employment were burdensome for him and the company. TM said if the company wanted to lay off Indonesian employees, the company was obliged to provide severance pay regardless of the reasons behind the termination of employment. Even though the reason behind the dismissal was due to the wrongdoing of an Indonesian employee, the company still had to provide severance pay. MT also admitted that there were Indonesian government regulations that were burdensome for him, for example, the stay period of only one year and the obligation of taking the Indonesian language proficiency test. TN also said that the length of stay was short while at the same time it would take a long time to process a Limited Stay Permit Card. In another perspective, NT had an objection regarding regulation when working on a holiday. In Japan, when someone works on holiday, they will get an additional day off for replacement in the next week. Meanwhile, in Indonesia, when there is overtime, there is no replacement day.

Furthermore, Kim (2001) affirms that host conformity pressure is the pressure that the host environment gives to individual immigrants to adopt a culture and communication system in the host environment. The difference in language is pressure for expatriates, particularly at the workplace because they have to work with local staff who do not speak their language. Therefore, all expatriates, the Japanese expatriates in this particular case, inevitably had to learn Indonesian in order to convey information or instructions as well as to discuss with the local staff with no miscommunication horizontally (among employees), vertically (from top to bottom or vice versa), or diagonally (cross-functional communication). 


\section{Mass Communication}

Kim (2001) declares that the use of mass communication, both media and nonmedia, can complement newcomers' knowledge. TM used Indonesian mass communications such as newspapers, television news, and Line Today to search for information. Sometimes he also looked for entertainment by watching Opera Van Java (OVJ) on Indonesian television channel. He also read reference books and Indonesian comics such as Doraemon comics to learn Indonesian. He further explained that by using mass communication, he could practice Indonesian by listening and acquiring new vocabulary. He knew slang word such as capek deh (tired), lebay (too much), and santai di pantai (being relaxed) because he watched OVJ programs. Not only that, he was also able to find out new regulations regarding companies and manpower as well as the current situation in Indonesia by watching news broadcasts on Indonesian television channels. Next, MT watched a news program on Trans TV. From that, he got information such as cases of kidnapping, robbery, and tours in Indonesia. He also read gossip magazines such as "Gosip" and Indonesian children books to learn Indonesian. According to him, using gossip magazines was easier than newspapers that used a lot of affixes. He admitted that initially he learned Indonesian by listening to and seeing the lyrics of Peterpan and Noah band songs as well as watching dangdut on Youtube. Then TY and NT confessed that they never read newspaper. They used a dictionary and watched Indonesian television even though they still had difficulty understanding the program content.

Kim (2001) in the theory explains that the use of ethnic mass communication helps to relieve the pressure encountered by individual immigrants in dealing with the host environment because it can help fulfill the needs of newcomers for pleasure and relaxation. From the interviews, all expatriates admitted using Japanese mass communication while in Indonesia. The Indihome cable broadcast facility with the IndiJapan package and various other international TV stations was provided by the company in each Japanese expatriate official residence. The use of ethnic mass communication was helpful for finding news and entertainment because they did not need to linguistically process the information conveyed. This was because it used Japanese language.

\section{Predisposition}

Kim (2017) also discloses that the adaptation of newcomers gets influence not only from the environment but also by the condition of the newcomers themselves. It also prevails to the expatriates. Before they experience a cross-cultural adaptation process, they must have pre-existing characteristics which are embedded in themselves previously. These internal conditions or characteristics can either help or hinder expatriates from adjusting to their circumstances. From the interview results, it can be seen that all expatriates had the readiness to accept challenges in dealing with different cultures.

Kim (2001) elucidates that the readiness of the newcomers or expatriates is obtained through formal education, training or previous experience of interacting with foreign cultures, voluntary attitudes and the nature of a sudden or planned transition to a new environment. From the results of the interview with four Japanese expatriates, they did not formally undertake the preparatory stage to work in Indonesia. The four of them did not receive training or learning facilities from the headquarters in Japan. Even so, the four ex-pats admitted that while in Japan they were doing their search for information independently. Information searches were carried out when expatriates 
were still in Japan before going to work in Indonesia.

TM admitted that he had time to find out about food through books and read books about the risks of doing business in Indonesia. He mentioned that he knew phrases in Indonesian through a dictionary namely "terima kasih" (thanks), "maaf" (sorry), and "saya lapar"(I am hungry). Furthermore, MT only had time to learn Indonesian through a dictionary. However, he did not remember the lessons at all when he arrived in Indonesia. Next, TY admitted that he had searched for information via Wikipedia about Indonesia and the city of Semarang. He found data related to population, religion, culture, food, and war history. Likewise, NT once searched for information via the internet about climate, the character of the population, and tourist attractions. However, from the search results, the information obtained was more beneficial for traveling. She had also studied Indonesian language with Indonesian people for five meetings with a duration of 1 hour for each meeting. From this learning, she got some information like things related to numbers, greetings, and how to read. However, just like MT, NT did not remember anything after arriving in Indonesia. Although TY and NT conducted information searches first, the information obtained was too minimal to introduce Indonesian cultural characters, especially for work.

\section{Intercultural Transformation}

As newcomers undergo cross-cultural adaptations, they will gradually experience cross-cultural transformation. Kim (2001) states that the learning process and daily activities carried out continuously within the culture of the host environment will make the individuals achieve harmony between internal responses within themselves and external realities in the new environment they encounter. For example, Japanese expatriates experienced a decrease in miscommunication as they began to adapt to Indonesian culture, including Indonesian language and its customs. Moreover, when adapting to the host country, Japanese expatriates could find ways to solve problems. Therefore, they got satisfactory results.

In general, Japanese expatriates believed that there was a change in themselves because they worked in a new environment that was different from their own culture. TM said that Indonesia had become a part of him. It was because he thought that he already had strong ties with Indonesia. He also felt comfortable living in Indonesia because Indonesia is a country that is comfortable to live in like Japan. He also said that while in Japan, he unconsciously practiced habits that were done during in Indonesia. He often spontaneously used Indonesian to Japanese people. From the interview with $\mathrm{TM}$, he seemed to have difficulty answering questions about the differences between Japan and Indonesia. This was because there had been a mixture of cultures in him. TM's statement is in line with Kim's (2001) statement regarding universalization which mentions that if a person undergoes intercultural transformation, he will see a difference as a unique thing with one goal.

The next expatriate, MT, felt that Indonesia was a part of him. He brought several habits he did in Indonesia to Japan like greeting supermarket staff, which was not common in Japan. Next, TY said that in the past he thought that Japanese way of working was the best way, but after working in Indonesia he became more open, and his Japanese mindset was less fixated. Unlike TM and MT, TY did not get the feeling that Indonesia was a part of him because of the short duration of stay and work. Currently, he admitted that he was still in the learning stage to assimilate Indonesian culture. Different from other expatriates, NT had not felt any changes in herself. The reason behind this statement was because she still did not much know about her duties and 
Indonesian language. It was her first time working in a factory and her Indonesian language was still very limited. She admitted that she was still undergoing an adaptation process to understand Indonesia fully.

\section{Stages of the Intercultural Adaptation Process}

When a person is in a different culture, there is an adaptation process undertaking. The adaptation process is divided into several stages. From the interview results, the stages that Japanese expatriates went through at SKB were figured out. The first stage was called preparation stage. From the above explanation, it can be shown that the four Japanese expatriates made preparations informally and independently. Informal training is training conducted outside the companies' facility. They did not receive training or learning facilities from the headquarters in Japan. Independent preparation means that the search for information is carried out independently. Therefore, it can be said that in this case of the object under study, the preparation stage was almost non-existent. The next stage was active stage. From the findings, all expatriates had different host communication competencies. All expatriates claimed to encounter differences in work culture with local staff, consider local staff as colleagues, and use Indonesian mass communication to seek information and learn. Also, almost all expatriates had relationship with their own ethnic group by joining Japan's Club, and used Japanese mass communication while in Indonesia.

Functionally, the main reason for the Japanese expatriates to go through adaptation process was because they had to perform their function and role in their job well. As people who had high positions and great responsibility for the company, they must be successful in their international duties so that the company would be satisfied with their performance. Hence, it can be said that they were carrying out an adaptation process related to the demands of their work. Therefore, the expatriate functional relationship could be divided into two: one related to their function regarding their position in the company, and the other was correlated with the responsibilities attached to them regarding their function outside the company as they also had to adapt to them Indonesians outside the office. For instance, outside the office, they interacted with Indonesian drivers and helpers. If they did not try to communicate with a driver, for example, they would not be able to ask the driver to take them to the desired place or anywhere outside the office since the driver obviously did not speak Japanese or English.

Final stage was the last one. From the findings, TY and NT were not yet at this stage. Both of them were still struggling in active stage. This was because their knowledge was still limited both in the Indonesian language and culture. It was also because the duration of their work and stay in Indonesia had not reached one year. However, it was different from the case of TM and MT. Both have reached final stage because they knew more about Indonesian language and culture. They have also sensed a culture mix in them.

\section{Conclusion}

The research results reinforce that adaptation process plays an important role particularly in two areas, i.e., task orientation and work colleagues. Adaption particularly with local staff, i.e., (1) Helping to complete tasks that became the responsibility of Indonesian workers, (2) Establishing a comfortable interaction with Indonesian employees could reduce miscommunication at work and minimize potential conflict with local staff. From the research findings, Japanese expatriates in Indonesia, 
particularly those who work at SKB, experience different adaptation processes. The adaptation process for the four expatriates depends on two things. First, how long they have lived and worked in Indonesia. Two Japanese ex-pats who have lived and worked in Indonesia for 22 and 7 years accordingly feel comfortable working and interacting with local staff. However, they still have not found comfort in interacting with Indonesians outside the company they work at. Meanwhile, Japanese expatriates who work for less than one year has not found a level of comfort in working and interacting with Indonesian employees or Indonesian citizens outside the company. Secondly, the adaptation process depends on their Indonesian language communication skills. The more capable Japanese expatriates are in speaking and understanding Indonesian, the more efficiently the Japanese expatriates do their jobs within the company and coordinate with local staff. Mastery of Indonesian language is also a determining factor in the adaptation process stages that the Japanese expatriates undertake. Not all informants in this research experience all adaptation stages because it depends on their competence in Indonesian language, the length of time they work in Indonesia, the comfort they get when they live and work in Indonesia, and the feeling of being part of Indonesia.

This research also finds that in the adaptation process, Japanese expatriates depend very little on the efforts of the company but more on their independent efforts in identifying the destination country. This is because the company provides no formal or informal training to introduce Indonesia before an expatriate is assigned. Some important factors in the adaptation process of Japanese expatriates in Indonesia particularly in SKB, apart from competence in Indonesian language, are understanding and adjusting to local work culture; media uses such as televisions, magazines, song lyrics, children books, and memos; interaction with Indonesians; and interaction with Japanese people or communities in Indonesia.

Therefore, it can be concluded that there are two categories of critical points in the adaptation process of Japanese expatriates in SKB in Indonesia. The intended critical points denote to those that must be carried out in the adaptation process. Otherwise, the adaptation process will presumably fail. The first point is related to Indonesian language skills. The four Japanese expatriates must master Indonesian language because it is very influential to their work. When Japanese expatriates' ability to understand Indonesian language is weak, it will result in more tremendous pressure within themselves to succeed, and the percentage of miscommunication with Indonesian employees is getting higher. Moreover, for expatriates who understand Indonesian language, interaction with Indonesians, particularly the company employees, will be much better. The second point is individual character. The character that Japanese expatriates have to have during the adaptation process is being willing to accept change. With this character, they will find it easier to deal with cultural differences and adapt to Indonesian employees. This attitude of willing to accept changes must be acquired since they are still in their home country so that they do not depend on the company that will send them to the destination country.

Although this study focuses on analyzing five factors in the adaptation process, this study also describes how informants experience the stress-adaptation-growth adaptation process, how the pressures of differences in language and culture they face cause stress, how they adapt to these differences, how the informants finally manage to cope with those matters, and how they undergo changes regarding their mindset and culture mix in themselves also appear in this study. 


\section{References}

Ahn, J. S., \& Kim, Y. S. (2015). Communication Experience of North Korean Defectors in Los Angeles: An Exloratory Interview Study of Cross-Cultural Adaptation. International Journal of Arts and Humanities , 1 (1), 13-24.

Aminullah, Lestari, P., \& Tripambudi, S. (2015). Model Komunikasi Antarbudaya Etnik Madura dan Etnik Melayu. Jurnal Komunikasi ASPIKOM , 2 (4), 272-281.

Anjalin, U., Mazumdar, A., \& Whiteside, E. (2017). Asian Students' Experience of Culture Shock and Coping Strategies. Journal of Education and Social Development , 1 (1), 7-13.

Arfiani, F., \& Febri, R. (2013). There is No Textbook Approach: Overcoming the Culture Shock Process through the Eyes of Australian Expatriates Working in Jakarta, Indonesia. CCI Conference on Corporate Communicatio (p. 13). New York: Emerald Group Publishing.

Burgess, T. (2016, August 20). International Assignment Failure and Tracking Methods. (DVV Media HR Group Ltd) Retrieved January 5, 2020, from Forum Expatriate Management: https://www.forum-expatmanagement.com/posts/11414-international-assignment-failure-and-trackingmethods

Central Java Provincial Government. (2020, Februari 5). Antisipasi Penyebaran Corona, Ribuan TKA Tiongkok Diawasi. Retrieved from Jatengprov.go.id: https://jatengprov.go.id/beritaopd/antisipasi-penyebaran-corona-ribuan-tkationgkok-diawasi/

Cordovez, A. C. (2018). Intercultural Orientation and Support When Living as a Hispanic-American Expatriate in Jakarta. Jurnal Komunikasi Indonesia , 7 (1), 17-27.

Creswell, J. W., \& Poth, C. N. (2018). Qualitative Inquiry \& Research Design: Choosing Among Five Approaches (5th ed.). Thousand Oaks, CA: Sage Publications.

Denzin, N. K., \& Lincoln, Y. S. (2018). The Sage Handbook of Qualitative Research (5th ed.). Thousand Oaks, CA: Sage Publications.

Dewi, N. R., \& Susilawati, E. (2018). The Influence of ICT and Pop Culture on Behavior Shift in Students of 2016 at UNIKOM English Literature Study Program . UNIKOM , $16(1), 3-10$.

Febiyana, A., \& Turistiati, A. T. (2019). Komunikasi Antarbudaya dalam Masyarakat Multikultural: Studi Kasus pada Karyawan Warga Negara Jepang dan Indonesia di PT Tokyu Land Indonesia. Jurnal Lugas , 3 (1), 33-44.

Ganapathi, N., \& Panchanatham, N. (2014). The Role of Human Resource Management in Cross-Cultural Environment:The Way to Managerial Communication. Exclusive Management Science , 3 (1), 1-8.

Hapsari, R. N. (2019). Adaptasi Komunikasi Budaya Mahasiswa Papua di Surabaya. Voxpop , 1 (1), 45-54.

Imelda, D., \& Elsera, M. (2018). Strategi Adaptasi Budaya Para Ekspatriat di Tanjungbalai Karimun. Jurnal Masyarakat Maritim, 2 (1), 24-32.

Inkson, K., Pringle, J., Arthur, M. B., \& Barry, S. (1997). Expatriate Assignment Versus Overseas Experience: International Human Resource Development. Journal of World Business , 32 (4), 351-368.

Jerolmack, C., \& Khan, S. R. (2018). Approaches to Ethnography: Analysis and Representation in Participant Observation. Oxford, Inggris: Oxford University 
Press.

Kang, S., Yossuck, P., Panyadee, C., \& Ek-lem, B. (2019). Influencing Factors of Cross-cultural Adaptation Process of Chinese Students Studying in the Upper Northern Thai Universities. Mediterranean Journal of Social Sciences , 10 (1), $65-74$

Kaye, M., \& Taylor, W. G. (1997). Expatriate Culture Shock in China: A Study in The Beijing Hotel Industry. Journal of Managerial Psychology , 12 (8), 496-510.

Kim, Y. S. (2008). Communication Experiences of American Expatriate in South Korea: A Study of Cross-Cultural Adaptation. Human Communication , 11 (4), 505-522.

Kim, Y. Y. (2001). Becoming Intercultural: An Integrative Theory of Communication and Cross-Cultural Adaptation. Thousand Oaks, CA: Sage Publications.

Kim, Y. Y. (2017). Integrative Communication Theory of Cross-Cultural Adaptation. New Jersey, NJ: Jhon Wiley \& Sons.

Kirana, R. P. (2012). Strategi Adaptasi Pekerja Jepang Terhadap Culture Shock: Studi Kasus Terhadap Pekerja Jepang di Instansi Pemerintah di Surabaya. Japanology, $1(1), 1-11$.

Laksamana, A. (2010). Internal Public Relations: Strategi Membangun Reputasi Perusahaan. Jakarta, Indonesia: Republika.

Liu, S., Volcic, Z., \& Gallois, C. (2015). Introducing Intercultural Communication: Global Culture and Contexts. London, Inggris: Sage Publications.

Lustig, M., \& Koester, J. (2010). Intercultural Competence: Interpersonal Communication Across Culture. London, Inggris: Pearson Education.

Mihayo, A. (2019). Cultural Shock Among African Students in Indonesia. ELS Journal on Interdisciplinary Studies in Humanities , 2 (1), 1-13.

Miles, M. B., Huberman, A. M., \& Saldana, J. (2014). Qualitative Data Analysis: A Methods Sourcebook (3rd ed.). Thousand Oaks, CA: Sage Publications.

Mitrovic, M., \& Vujovic, M. (2017). Intercultural Non-Verbal Communication from The Perspective Of Serbian Communication Students. Balkan Social Science Review, 10, 115-131.

Nathaniel, F. (2019, November 25). Betulkah Tenaga Kerja Asing Tambah Angka Pengangguran Indonesia. Retrieved from Tirto: https://tirto.id /betulkah-tenagakerja-asing-tambah-angka-pengangg uran-indonesia- emcC

Neuman, W. (2014). Social Research Methods: Qualitative and Quantitative Approaches (7th ed.). New York, NY: Pearson Education.

O'Reilly, K. (2009). Key Concepts in Ethnography. London, Inggris: Sage Publications.

Pemerintah Provinsi Jawa Tengah. (2020, Februari 5). Antisipasi Penyebaran Corona, Ribuan TKA Tiongkok Diawasi. Retrieved from Jatengprov.go.id: https://jatengprov.go.id/beritaopd/antisipasi-penyebaran-corona-ribuan-tkationgkok-diawasi/

Perdhana, M. S., Sawitri, D., \& Siregar, R. A. (2019). Adjusting to Indonesia's Culture: The Case of Expatriates in The Education Industry. Journal of Educational, Health, and Community Psychology, 8 (4), 500-516.

Rahardjo, T., Dwiningtyas, H., \& Pradekso, T. (2018). Komunikasi Penyesuaian Diri Kembali Pekerja Migran Perempuan yang Kembali ke Daerah Asal. Jurnal Komunikasi ASPIKOM , 3 (5), 817-832.

Rajasekar, J., \& Renand, F. (2013). Culture Shock in A Global World: Factor Affecting Culture Shock Experienced by Expatriates in Oman and Omani Expatriate 
Abroad. Business and Management, 8 (13), 144-160.

Rodsai, T., Stoffers, J., \& Talim, B. (2017). Cross-Cultural Adjustment: A Case of Thai Expatriates in Indonesia. Journal of Applied Business Research (JABR) , 33 (6), $1139-1152$.

Saihu. (2019). Harmony Hindu-Muslim in Bali Through Local Wisdom: Study in Jembrana District. Jurnal Multikultural \& Multireligius , 19 (1), 7-27.

Samovar, L. A., Porter, R. E., McDaniel, E. R., \& Roy, C. S. (2017). Communication Between Cultures (14th ed.). Boston, MA: Cengage Learning.

Santoso, T., Elyadi, R., \& Satriany, M. D. (2018). Kompetensi Lintas Budaya GuruGuru Ekspatriat di Kota Semarang. Jurnal Ekonomi, Manajemen, Akuntansi, dan Perpajakan, 1 (2), 277-292.

Santra, T., \& Giri, V. N. (2009). Analyzing Computer-Mediated Communication and Organizational Effectiveness. Review of Communication , 9 (1), 100-109.

Semmler, K. M., \& Kim, Y. Y. (2014). Cross-Cultural Adaptation of Hispanic Youth: A Study of Communication Patterns, Functional Fitness, and Psychological Health. Communication Monographs , 81 (2), 133-156.

Shi, L., \& Wang, L. (2013). The Culture Shock and Cross-Cultural Adaptation of Chinese Expatriates in International Business Context. International Business Research, 7 (1), 23-33.

Soemantri, N. P. (2019). Adaptasi Budaya Mahasiswa Asal Indonesia di Australia. WACANA , $18(1), 46-56$.

Somad, M. A. (2020). Komunikasi dalam Pasangan Pernikahan Beda Etnis: Studi pada Etnis Bugis dan Etnis Banyuasin di Desa Sungsang I Kecamatan Banyuasin II (Bachelor's thesis). Universitas Islam Negeri, Palembang, Sumatera Selatan.

Sommier. (2012). Exploring The Phenomenon of Host Conformity Pressure (Master's thesis). University of Jyväskylä, Jyväskylä, Finland.

Turistiati, A. T. (2016). Intercultural Communication Competence: Its Important to Adaptation Strategy Towards People with Different Cultural Background. Ijtimā'iyya: Journal of Muslim Society Research , l (1), 63-78.

Widiyaningrum, M. (2017). Adaptasi Mahasiswa Asing di Universitas Muhammadiyah Surakarta (Bachelor's thesis). Universitas Muhammadiyah Surakarta, Surakarta, Jawa Tengah.

Yurianti, M., Pranawa, S., \& Yuhastina. (2020). UNS Foreign Students Adaptation Strategies in Facing Culture Shock in Solo. Jurnal Pendidikan Ilmu-ilmu Sosial, $12(2), 407-416$.

Yusof, A. A. (2000). Pembangunan Ekspatriat dalam Konteks Pengurusan Sumber Manusia Antarabangsa. Sintok, Malaysia: Universiti Utara Malaysia. 